\title{
Case note on CJEU (Grand Chamber), judgement of 19 December 2018, C-219/17, Silvio Berlusconi and Finanziaria d'investimento Fininvest SpA (Fininvest) v Banca d'Italia and Istituto per la Vigilanza Sulle Assicurazioni (IVASS)
}

Citation for published version (APA):

Dermine, P., \& Eliantonio, M. (2019). Case note on CJEU (Grand Chamber), judgement of 19 December 2018, C-219/17, Silvio Berlusconi and Finanziaria d'investimento Fininvest SpA (Fininvest) v Banca d'Italia and Istituto per la Vigilanza Sulle Assicurazioni (IVASS). Review of European Administrative Law, 12(2), 237-253. https://doi.org/10.7590/187479819X15840066091330

Document status and date:

Published: 01/01/2019

DOI:

$10.7590 / 187479819 \times 15840066091330$

Document Version:

Publisher's PDF, also known as Version of record

Document license:

Taverne

Please check the document version of this publication:

- A submitted manuscript is the version of the article upon submission and before peer-review. There can be important differences between the submitted version and the official published version of record. People interested in the research are advised to contact the author for the final version of the publication, or visit the DOI to the publisher's website.

- The final author version and the galley proof are versions of the publication after peer review.

- The final published version features the final layout of the paper including the volume, issue and page numbers.

Link to publication

\footnotetext{
General rights rights.

- You may freely distribute the URL identifying the publication in the public portal. please follow below link for the End User Agreement:

www.umlib.nl/taverne-license

Take down policy

If you believe that this document breaches copyright please contact us at:

repository@maastrichtuniversity.nl

providing details and we will investigate your claim.
}

Copyright and moral rights for the publications made accessible in the public portal are retained by the authors and/or other copyright owners and it is a condition of accessing publications that users recognise and abide by the legal requirements associated with these

- Users may download and print one copy of any publication from the public portal for the purpose of private study or research.

- You may not further distribute the material or use it for any profit-making activity or commercial gain

If the publication is distributed under the terms of Article 25fa of the Dutch Copyright Act, indicated by the "Taverne" license above,

Download date: 26 Apr. 2023 


\section{Case Note: CJEU (Grand Chamber), Judgment of 19 December 2018, C-219/17, Silvio Berlusconi and Finanziaria d'investimento Fininvest $S p A$ (Fininvest) $v$ Banca d'Italia and Istituto per la Vigilanza Sulle Assicurazioni (IVASS)}

Paul Dermine*

PhD candidate, Maastricht University

Mariolina Eliantonio

Professor of European and Comparative Administrative Law and Procedure, Maastricht University

\section{Introduction}

The topic of shared administration, or composite procedures, is one which has not only attracted considerable scholarly attention in the last years ${ }^{1}$, but also come increasingly often to the attention of the Court of Justice. While the existence of composite procedures (definable as decision-making processes involving multiple jurisdictions participating at different moments and with different intensities) ${ }^{2}$ is not a new phenomenon and has virtually existed since the beginning of the project of European integration, it is in the last years that several interesting questions have been brought to the attention of the Court of Justice, with the aim of clarifying, in particular, the judicial implications of this system of administrative governance. ${ }^{3}$ Indeed, whereas the system of decision-making for the implementation of EU law is increasingly shared and composite in nature, the system of judicial protection has remained in principle anchored to a model based on domestic jurisdiction, whereby the court competent to review a certain administrative act or action is the court

DOI 10.7590/187479819X15840066091330 1874-7981 2019 Review of European Administrative Law

1 M. Eliantonio, 'Judicial review in an integrated administration: the case of "composite procedures"' (2014) 7 REALaw 65; F. Brito Bastos, 'The Borelli Doctrine Revisited: Three Issues of Coherence in a Landmark Ruling for EU Administrative Justice' (2015) 8 REALaw 269; F. Brito Bastos, 'Derivative Illegality in European Composite Administrative Procedures' (2018) 55 CMLR 101; J. Fernández Gaztea, 'A Jurisdiction of Jurisdictions' (2019) 12 REALaw 1. With regard to composite procedures involving agencies: M. Scholten and M. Luchtman (eds), Law Enforcement by EU Authorities: Implications for Political and Judicial Accountability (Edward Elgar 2017). With regard to composite procedure involving data sharing activities, see the special issue $20(1)$ of European Public Law (2014). In relation to pharmaceuticals authorisations see S. RöttgerWirtz and M. Eliantonio, 'From Integration to Exclusion: EU Composite Administration and Gaps in Judicial Accountability in the Authorisation of Pharmaceuticals' (2010) 10 EJRR 393.

2 See for this definition, M. Eliantonio (n1) 65 .

3 See for instance case C-562/12 Liivimaa Lihaveis MTÜ [2014] EU:C:2014:2229. 
belonging to the legal system in which the act or action is imputable, regardless of whether it is part of a larger multi-jurisdictional decision-making process.

In the Borelli case, ${ }^{4}$ the Court of Justice was faced with an important question concerning the division of labour between itself and the national courts in a composite procedure, a case which has remained unchanged and unchallenged to date. Twenty-five years later, the Berlusconi case adds an important piece to the puzzle of the mechanism establishing the division of labour in composite procedures. ${ }^{5}$ However, it also leaves a number of questions still open. Crucially, as the ruling consecrates a generous understanding of the Court's jurisdiction in composite procedures, it begs further questions and raises new issues.

This case note proceeds as follows: first, it presents the facts of the case; secondly, it analyses the ruling of the Court and, where relevant, the opinion of the Advocate General (AG); thirdly, it discusses a number of implications arising from the ruling, and places it in the wider context of the Court's case law on the ECB and European multi-level administrative governance. In particular, this case note argues that, while unsurprising in the context of earlier case law on composite procedures, the Berlusconi ruling contributes to clarifying the conditions and modalities of the Court's jurisdiction in composite procedures, but still leaves a number of unanswered questions concerning the 'reach' of judicial review when shared administration is at stake.

\section{Facts of the case}

This case arose in the context of the new Banking Union set up following the Eurozone crisis. ${ }^{6}$ It concerns the former Italian Prime Minister Silvio Berlusconi and his holding company Fininvest. In the 1990s, Fininvest acquired around $30 \%$ of the shares of a mixed financial holding company, named Mediolanum SpA, which included, among others, a bank, Banca Mediolanum. In 2013, following proceedings which went all the way up to the Italian Corte di Cassazione, Silvio Berlusconi was found guilty of tax fraud and, as a result, was disqualified from public office and managing corporations for a period of two years. Under European law, holders of qualifying holdings in credit institutions must fulfill a certain number of criteria. Among others, Article 23 of the 'Capital Requirements Directive' (also known as 'CRD IV') ${ }^{7}$ establishes

4 Case C-97/91 Oleificio Borelli v Commission [1992] EU:C:1992:491.

5 For another analysis of the case, see F. Brito Bastos, 'Judicial review of composite administrative procedures in the Single Supervisory Mechanism: Berlusconi' (2019) 56 CMLR 1355 .

6 In general, see D. Busch and G. Ferrarini, European Banking Union (OUP 2015); G Lo Schiavo (ed), The European Banking Union and the Role of Law (Edward Elgar 2019); F. Martucci, L'union bancaire (Bruylant 2016).

7 Directive 2013/36/EU of the European Parliament and of the Council of 26 June 2013 on access to the activity of credit institutions and the prudential supervision of credit institutions and investment firms, amending Directive 2002/87/EC and repealing Directives 2006/48/EC and 2006/49/EC [2013] OJ L176/338. The Directive forms part of the so-called 'Single Rulebook', 
that such holders must be deemed 'suitable', in light of their reputation, knowledge, skills and experience. The relevant provision (Article 25) of the Italian 'Consolidated Law on Banking' transposing the CRD IV similarly requires these holders to be of 'good reputation' and to satisfy criteria of 'competence and integrity', in order to ensure the sound and prudent management of banks. Upon his conviction, the Italian financial supervisory authorities, the Banca d'Italia, and the Istituto per la vigilanza sulle assicurazioni (IVASS) initiated a procedure which, in 2014, resulted in a decision finding that Silvio Berlusconi no longer fulfilled the reputation requirement, and therefore imposing that Fininvest's holdings in Mediolanum be limited to under 10\%. Berlusconi and Fininvest challenged that decision before the Italian courts, and ultimately were successful before the Consiglio di Stato, which annulled the decision of Banca d'Italia, for reasons pertaining to the temporal applicability and the retroactive application of the relevant Italian legislation.

In the meantime, via a merger by 'reverse integration', Mediolanum was acquired by, and incorporated into, its subsidiary Banca Mediolanum. The merger was approved by Banca d'Italia, however considering later that, as a result of the operation, Fininvest had acquired a qualifying holding directly in a financial institution. In line with guidance provided by the European Central Bank (ECB), Banca d'Italia considered that a fresh authorization related to the acquisition of this new holding was required, and urged Fininvest to submit an application in that regard. That request was not acted upon and Banca d'Italia commenced an administrative procedure on its own initiative. The procedure culminated in the ECB, which had become competent on the matter under the newly established Single Supervisory Mechanism (SSM). The ECB thus adopted a decision on 25 October 2016 finding that the indirect acquirer of the qualified holding in Banca Mediolanum, namely Silvio Berlusconi, did not meet the reputation requirement, and was doubtful as to his 'ability to ensure that Banca Mediolanum would be managed soundly and prudently in the future'. ${ }^{8}$ As a consequence, the acquisition of the qualifying holding in Banca Mediolanum by Silvio Berlusconi and Fininvest was opposed by the ECB.

Under the newly established SSM framework, the granting of authorizations for acquisitions of qualifying holdings in credit institutions is subject to a complex administrative procedure, organized by Articles 4(1)(c), 6(4) and 15 of

which incorporates into EU law the 'Basel III agreements', i.e. a harmonized set of prudential measures developed by the Basel Committee on Banking Supervision in response to the financial crisis.

8 ECB Decision of 25 October 2016, ECB/SSM/20016-7LVZJ6XRIE7VNZ4UBX81/4, not made public. 
the SSM Regulation, ${ }^{9}$ and Articles 85 to 87 of SSM Framework Regulation..$^{10}$ It culminates with a final decision by the ECB, which therefore enjoys an exclusive decision-making power. ${ }^{11}$ However, following a multi-level pattern, it closely involves national authorities in charge of financial supervision (known as 'national competent authorities' or NCAs) which intervene at all stages of the procedure, and issue different acts, of a preparatory nature, in that context. ${ }^{12}$ NCAs collect notifications of acquisitions, and forward them to the ECB. They conduct a first assessment of the proposed acquisitions that are notified to them, in light of the relevant legislative requirements. On that basis, they prepare draft decisions (to oppose or not to oppose the acquisition) that they pass on to the ECB, which shall then conduct its own assessment and take the final decision. This is the reason why Banca d'Italia, and to a lesser extent IVASS, were closely associated in the procedure at stake, most notably by collecting the necessary information, and by proposing, in a draft decision submitted on 23 September 2016, that the acquisition ought to be opposed, for the main reason that its acquirers did not meet the reputation requirement.

That ECB decision is currently subject to an action for annulment before the General Court of the European Union, jointly launched by Silvio Berlusconi and Fininvest. ${ }^{13}$ An azione di ottemperanza (i.e. an action to seek compliance

9 Council Regulation 1024/2013 of 15 October 2013 conferring specific tasks on the European Central Bank concerning policies relating to the prudential supervision of credit institutions [2013] OJ L287/63.

10 Regulation $468 / 2014$ of the European Central Bank of 16 April 2014 establishing the framework for cooperation within the Single Supervisory Mechanism between the European Central Bank and national competent authorities and with national designated authorities [2014] OJ L141/1.

11 It is important to emphasize that the ECB exercises this authorization competence with regard to all banks, whatever their size or importance. These types of procedures, often referred to as common procedures, are fully centralized, and therefore derogate from the general division of labour under the SSM, according to which the ECB only directly supervises significant financial institutions, while banks deemed less significant remain in principle under the surveillance of NCAs. In that regard, see Article 6(4)(5) of the SSM Regulation. On this division of tasks, see Case T-122/15 Landeskreditbank Baden-Württemberg - Förderbank v European Central Bank [2017] EU:T:2017:337, paras 20-29. See also C. Brescia Mora, 'The Interplay between the ECB and NCA's in the "Common Procedures" under the SSM Regulation' (2018) 84 Banca d'Italia - Quaderni di Ricerca Giuridica della Consulenza Legale, 84-86.

12 The close cooperation between the ECB and NCAs is one of the defining features of the SSM. The reasons are of course manifold, but such strong involvement of national supervisors can be best explained by the youth of the ECB as a prudential authority, and the benefits it may gain from the expertise, experience, resources, and insider knowledge of NCAs. In that regard, see G. Lo Schiavo, 'The Single Supervisory Mechanism - Building a New Top-down Cooperative Supervisory Governance in Europe' in F. Fabbrini et al (eds), What Form of Government for the European Union and the Eurozone? (Hart 2015) 111-130. States participating in the SSM freely designate the national organ which is to act as NCA under the SSM framework (Article 2(2) of the SSM Regulation). Depending on the model they favor (integration or separation), the NCA will either be the national central bank, or a separate authority. In that regard, see M. Goldmann, 'United in Diversity? The Relationship between Monetary Policy and Prudential Supervision in the Banking Union' (2018) 14 EuConst 283, 283-310.

13 See Case T-913/16 Fininvest and Berlusconi v ECB, currently pending. 
with a court's ruling which has acquired the force of res judicata) was also brought before the Consiglio di Stato, in which the applicants requested the annulment of several preparatory acts adopted by Banca d'Italia in the framework of this procedure (most notably the draft decision of 23 September 2016) for disregarding the res judicata of the Consiglio di Stato's previous ruling.

It is in the framework of these national proceedings that the reference to the Court of Justice was made. The Consiglio di Stato sought clarification as to the nature of the authorization procedure set up by the SSM Regulation, the exact division of tasks between the ECB and the NCAs in that context, and its implications in terms of judicial review. It raised two questions. The first related to the scope of the Court's jurisdiction in the complex administrative procedure of authorization set up under the SSM: is it exclusive and total, encompassing the preparatory acts adopted at the national level, or split between the Court and national judiciaries, depending on the author of the act at stake? The second question related to a specific circumstance of the case, i.e. the existence of a previous ruling of the Consiglio di Stato which acquired the force of res judicata and the nature of the proceedings in the framework of which the reference was made (the azione di ottemperanza), and its influence on the Court's assessment. In view of its significance and landmark status, this case note primarily focuses on the first question only.

\section{Judgment of the Court}

In its ruling, the Court starts by explaining the different effects that the involvement of national authorities in the course of an administrative procedure, leading up to the adoption of an EU act (a composite administrative procedure), ${ }^{14}$ entails for 'the division of jurisdiction between EU courts and courts of the Member States'. ${ }^{15}$ In direct line with what had been suggested by AG Campos Sánchez-Bordona, ${ }^{16}$ the Court draws a clear distinction between two scenarios.

Under the first one, firstly identified in the Sweden $v$ Commission ruling, ${ }^{17}$ the involvement of national authorities in the complex administrative procedure only constitutes a stage of such procedure, and does not affect the exclusive and

14 Brito Bastos rightly points out that the concept is for the time ever used by the Court of Justice, in para. 38 of the Berlusconi ruling: F. Brito Bastos (n5) 1367.

15 Case C-219/17 Silvio Berlusconi and Fininvest v Banca d'Italia and IVASS [2018] EU:C:2018:1023 (Berlusconi), para. 40.

16 Case C-219/17 Silvio Berlusconi and Fininvest v Banca d'Italia and IVASS [2018] EU:C:2018:502, Opinion of AG Campos Sánchez-Bordona, paras 40, 57-79.

17 Case C-64/05 P Sweden v Commission [2007] EU:C:2007:802, paras 93-94. According to Brito Bastos, the choice of this case as reference point is rather surprising, as there would have been, in his Opinion, more relevant precedents. F. Brito Bastos (n5) 1369-1370. 
final decision-making power of the competent EU institution - for example by binding it through preparatory acts or proposals adopted by national authorities. In these cases, jurisdiction over the whole procedure belongs exclusively to EU courts, which are to rule not only on the legality of the final decision adopted by the EU institution, but also on 'any defects vitiating the preparatory acts or the proposals of the national authorities that would be such as to affect the validity of that final decision'. ${ }^{18}$ For the Court, such a single judicial review is warranted by Article 263 TFEU, read in light of the principle of sincere cooperation (Article 4(3) TEU). ${ }^{19}$ More specifically, the Court notes that, should national remedies against preparatory acts or proposals be tolerated, the risk of divergent assessments could not be ruled out and the Court's exclusive jurisdiction would be compromised. ${ }^{20}$ Such remedies are thus to be excluded, whatever their type, as well as the nature of the heads of claim or pleas put forward in their framework. $^{21}$

Under the second scenario (the Borelli scenario), ${ }^{22}$ the national authorities' involvement in the procedure is much more decisive, and constitutes 'a necessary stage of a procedure for adopting an EU act in which the EU institutions have only a limited or no discretion, so that the national act is binding on the EU institution'. ${ }^{23}$ National acts adopted in the framework of such procedures remain for the national courts to examine, while the European courts retain jurisdiction over the final EU measure.

In light of this distinction, the Court then moves to assess the complex administrative procedure at stake: the prior authorization of any acquisition of, or increase in, a qualifying holding in a credit institution, as primarily regulated by Article 4(1)(c) and 15 of the SSM Regulation and Articles 85 and 86 of the SSM Framework Regulation. More specifically, the Court's efforts focus on spelling out the specific division of tasks between the ECB and NCAs in that specific context. Its assessment, perfectly in line with that of AG Campos Sánchez-Bordona, ${ }^{24}$ is unequivocal: the authorization procedure belongs to the first scenario. ${ }^{25}$ Following Article 4(1)(c) of the SSM Regulation, the ECB is exclusively competent to decide on whether or not to authorize proposed acquisi-

\footnotetext{
Berlusconi, para. 45 .

Berlusconi, para. 47.

Berlusconi, para. 50.

Berlusconi, para. 51.

Case C-97/91 Oleificio Borelliv Commission [1992] EU:C:1992:491, paras 9-10.

Berlusconi, para. 45 .

The analysis carried out is however much more exhaustive. See Berlusconi, Opinion of AG Campos Sánchez-Bordona, paras 92-115.

25 Berlusconi, paras 53-56. In that regard, Brito Bastos uses the term of 'reverse Borelli' to describe the Berlusconi scenario. See F. Brito Bastos (n5) 1370-1375.
} 
tions. ${ }^{26}$ Moreover, if NCAs are to play a role in the procedure, that role is only supplementary, and not such as to challenge the exclusive decision-making power of the ECB. For example, the Court points out that NCAs are tasked with registering the applications for authorization, and with assisting the ECB throughout the procedure. It is in that context that they provide the ECB with the necessary information to conduct its assessments and, crucially, submit draft decisions, which do not however bind the ECB and are not notified to the applicant. $^{27}$

On that basis, the Court ruled that its exclusive jurisdiction does not only cover the final EU act at stake (i.e. the ECB decision of 25 October 2016 opposing the acquisition), but also 'as an incidental matter' ${ }^{28}$ the national preparatory acts adopted by Banca d'Italia, the defects and eventual unlawfulness of which may affect the legality of the final EU act. As a consequence, any jurisdiction of national courts in respect of those acts must be excluded, whatever the type of action launched before them. The specific fact that the action launched before the Consiglio di Stato was an azione in ottemperanza was therefore deemed irrelevant. $^{29}$

\section{The implications of the ruling: the division of labour between courts in the context of composite procedures}

4.1. The Berlusconi ruling in the context of the case law of financial supervision and of composite procedures: a new - but predictable - step?

The Berlusconi ruling forms part of a growing body of case law devoted to financial supervision in the European Union. ${ }^{30}$ The emergence of the SSM as a new vehicle for integration, endowed with novel and unprecedented features, ${ }^{31}$ has brought about new legal questions (for example, as to the nature

26 Berlusconi, para. 54. Such qualification of the ECB's competence as exclusive builds upon the Court's earlier findings in the Landeskreditbank Baden-Württemberg ruling (para. 54). Brito Bastos deems this terminological choice unfortunate, considering the fact that, in 'common procedures', the ECB's powers are shared (even though not equally) with the NCAs. F. Brito Bastos (n5) 1367 .

27 Berlusconi, para. 55 .

28 Berlusconi, para. 57.

29 Berlusconi, para. 58.

30 For a general overview, see M. Prek and S. Lefèvre, 'Le contentieux de la surveillance prudentielle des établissements de crédit devant le tribunal de l’Union européenne’ (2019) 250 Journal de droit européen 99.

${ }^{31}$ Boucon and Jaros have powerfully argued that 'the SSM breaks with traditional modes of European integration, and constitutes a hybrid mode of execution of EU law in the sense that: (i) it furthers European integration to the extent that supervision per se had been centralized in the hands of the ECB, but (ii) it limits European integration to the extent that it still leaves 
of this new legal construct, the division of tasks between the constitutive units of this novel administrative system, and the structure of judicial review) and prompted the Court of Justice to intervene in order to clarify certain aspects of the institutional architecture of the SSM. Berlusconi constitutes a milestone, as it contributed to disentangling the complex interplay between the ECB and national supervisors under the SSM framework. It makes sense of its repercussions on the structure of judicial review and the respective jurisdiction of national and EU courts, and sets a clear path for the judicial protection of those affected by the decisions taken under the SSM framework..$^{32}$

The Berlusconi ruling did certainly not come as a surprise. In view of the architecture of the SSM, its highly centralized nature, and more generally, the founding rationale of the Banking Union, ${ }^{33}$ it is only logical that the Court decided that its jurisdiction was also to encompass the preparatory acts adopted by national supervisory authorities. The ruling did however further assert and consolidate the position of the Court under this construct, and thereby contributes to exacerbate the supranational dynamics, and hierarchical nature, of the SSM. It is probably for this reason that the Court did not exclusively base its findings on its case law on composite administrative procedures and on the Sweden v Commission precedent, but also conveyed, in a somewhat convoluted manner: the effectiveness of decision-making under the SSM, ${ }^{34}$ the principle of effective judicial protection, ${ }^{35}$ and the duty of sincere cooperation. ${ }^{36}$ This trend had already been set in motion in the Landeskreditbank Baden-Württemberg - Förderbank ruling, where the Court established that the ECB had been transferred an exclusive competence regarding prudential supervision in the Eurozone, and that when intervening under the SSM framework, NCAs were not exercising a competence of their own, but were acting within the scope of decentralized implementation of an exclusive EU competence. ${ }^{37}$ Clearly, Berlusconi

it up to the Member States to decide how to supervise credit institutions covered by the SSM'. See L. Boucon and D. Jaros, 'The Application of National Law by the European Central Bank within the EU Banking Union's Single Supervisory Mechanism - A New Mode of European Integration?' (2018) 10 EJLS 182.

32 For early assessments on these issues, see L. Wissink, T. Duijkersloot and R. Widdershoven, 'Shifts in Competences between Member States and the EU in the New Supervisory System for Credit Institutions and their Consequences for Judicial Protection' (2014) 10 Utrecht L Rev 92; G. ter Kuile, L. Wissink and W. Bovenschen, 'Tailor-Made Accountability within the Single Supervisory Mechanism' (2015) 52 CMLR 180.

33 The Banking Union, as a political project, was primarily meant to end the fragmentation of financial markets in Europe, and to guarantee their stability and robustness.

Berlusconi, para. 49.

Berlusconi, para. 44 .

Berlusconi, para. 47 .

7 Case T-125/15 Landeskreditbank Baden-Württemberg - Förderbankv European Central Bank [2017] EU:T:2017:337, paras 50-64. This General Court ruling was confirmed on appeal by the Court of Justice. See Case C-450/17 P Landeskreditbank Baden-Württemberg - Förderbankv European Central Bank [2019] EU:C:2019:372. 
exacerbates the trend towards centralization and supranationalism, at the expense of transnationalism. ${ }^{38}$

From a more general perspective, Berlusconi also constitutes a welcome yet unsurprising - addition to the Court's case law on the structure of judicial review under complex administrative procedures. It makes clear that, in the system of composite procedures, the respective jurisdiction of national courts and the ECJ depends on the legal effects attached to national preparatory acts (binding or non-binding), and on the level of discretion retained by the final EU decision-maker. From this perspective, it fully confirms the earlier arguments advanced in doctrine with respect to the Court's position in relation to the so-called "derivative illegality" of EU measures based on unlawful national preparatory measures. ${ }^{39}$

In particular, in the Borelli situations, a number of EU constitutional arguments, namely the limits of the ECJ jurisdiction to review EU law measures and the autonomy of EU law as a legal order vis-à-vis that of the Member States seem to sustain the impossibility of "derivative illegality": if national preparatory measures were able to contaminate final EU measures, the autonomy of EU law would be threatened, and if the ECJ were able to review these measures, the prohibition for the EU courts to adjudicate on national measures would be by-passed. $4^{40}$ These arguments, however, do not function as a hurdle to the jurisdiction of the ECJ to review national preparatory measures in Berlusconi situations. This is because of at least one discernible difference between the two scenarios. In the Berlusconi scenario, the national error is implicitly ascribable to the EU level, because of the discretion enjoyed by the EU authorities to diverge from the national preparatory measure. The jurisdiction of the Court of Justice over national preparatory measures seems therefore much more justifiable than in Borelli situations where EU authorities bear no responsibility neither for making the error (made at the national level) eventually contaminating the EU measure, nor for endorsing it (given the lack of discretion available to the EU authority under such decision-making processes). Whenever the EU authorities fully endorse an invalid national preparatory measure (even though they had the power, and possibly the duty, to control its lawfulness), such as in Sweden $v$ Commission, ${ }^{41}$ or where they fail to correct procedural errors which occurred at national level but could have been rectified at the EU level, such as in France Aviation, ${ }^{42}$ the responsibility for the entirety of the composite decision-

38 E. Chiti and F. Recine, 'The Single Supervisory Mechanism in Action - Institutional Adjustment and the Reinforcement of the ECB Position' (2018) 24 EPL 101.

39 F. Brito Bastos (n1).

40 These arguments are further aptly discussed in F. Brito Bastos (n1) 110-113.

41 Case C-64/05 P Sweden v Commission [2007] EU:C:2007:802.

$4^{2}$ Case T-346/94 France-aviation v Commission [1995] EU:T:1995:187. 
making process rests at the EU level, and, as a consequence, the jurisdiction for the entirety of the composite decision-making process belongs to the ECJ. ${ }^{43}$

The imputability of the entire decision-making process to the EU level, arising as a consequence of the non-binding nature of the national preparatory measure and the margin of discretion afforded to the EU authorities with respect to the national measure therefore, in the Court's view, justifies a solution not merely different, but one opposite ${ }^{44}$ to the strict denial of "derivative illegality" advanced in Borelli. Hence, a solution on the basis of which national courts are forbidden from adjudicating on the national measures which are part of a composite procedure culminating at EU level, with the sole jurisdiction for these measures belonging to the European courts.

4.2. Berlusconi and Rimšēvičs: expansive move on the part of the CJEU?

As a ruling which contributes to expanding the potential or actual reach of the Court's jurisdiction, the Berlusconi ruling ought to be read in parallel with another decision rendered two months later, in a distinct but related context: the Rimšēvičs judgment. ${ }^{45}$ Rimšēvičs was decided in the context of the operations of the European System of Central Banks (ESCB), and concerned the validity of a decision by the Latvian anti-corruption office to temporarily suspend from office the governor of the Central Bank of Latvia, $\mathrm{Mr}$ Rimšèvičs, in view of ongoing criminal prosecutions and the various charges pending against him. That decision was challenged by both Mr Rimšēvičs and the ECB itself, which argued that there were no indications of a serious misconduct, and that the removal thereby undermined the principle of central bank independence enshrined in Articles 130 and 131 TFEU. Applicants based their

Along the same lines see F. Brito Bastos (n1).

The idea of Berlusconi opting for an 'opposite' solution than the one proposed in Borelli is advanced by F. Brito Bastos (n5) 1370-1375.

Cases C-202/18 and C-232/18 Ilmārs Rimšēvičs and European Central Bank v Republic of Latvia [2019] EU:C:2019:139 (Rimšêvičs). On this decision, see D. Sarmiento, 'Crossing the Baltic Rubicon' (Verfassungsblog, 4 March 2019) verfassungsblog.de/crossing-the-baltic-rubicon/ accessed 11 October 2019; J. Bast, 'Autonomy in Decline? A Comment on Rimsevics and ECB v Latvia' (Verfassungsblog, 13 May 2019) verfassungsblog.de/autonomy-in-decline-a-commentary-on-rimsevics-and-ecb-v-latvia/ accessed 11 October 2019; M. Costa, 'Accountability and Independence of the Governors of National Banks - Any Role for the CJEU?' (EULawAnalysis, 25 March 2019) eulawanalysis.blogspot.com/2019/03/accountability-and-independence-of.html accessed 11 October 2019; R. Smits, 'ECJ annuls a national measure against an independent central banker' (European Law Blog, 5 March 2019) europeanlawblog.eu/2019/03/o5/ecj-annulsa-national-measure-against-an-independent-central-banker/ accessed 11 October 2019; P-E. Pignarre, 'Anatomie d'une première: Le contrôle de légalité d'une mesure nationale par la CJUE' (Blog de Droit Européen, 9 May 2019) blogdroiteuropeen.com/2019/05/o9/anatomiedune-premiere-le-controle-de-legalite-dune-mesure-nationale-par-la-cjue-par-pierre-emmanuelpignarre/ accessed 11 October 2019. 
action on Article 14.2 of the Statute of the ESCB, a remedy which had never been activated before. According to that provision, decisions relieving governors of national central banks from office may be referred to the Court of Justice by the relieved governor or by the ECB Governing Council 'on grounds of infringement of the EU Treaties or of any rule of law relating to its application'. Central and ground-breaking in Rimšēvičs was the Court's assessment of the nature of that atypical remedy, and the effects born by the Court orders issued in that context. In a nutshell, the Court was asked to choose between two possible options: did that remedy constitute an infringement procedure of some sort, leading to a merely declaratory judgment, to be followed upon by national authorities (along the lines of Articles 258 to 260 TFEU)? Or did it amount to a specific type of annulment action, which could produce cassatory effects (following the logic of Article 263 TFEU)? Despite the fact that both applicants (Mr Rimšêvičs and the ECB) and AG Kokott ${ }^{46}$ had argued along the lines of the first view, the Court unexpectedly favored the second. Having found that Latvia had failed to establish that the decision to relieve Mr Rimšēvičs from office was based on sufficient indications he had engaged in serious misconduct, ${ }^{47}$ the Court directly annulled the contested decision by the Latvian anti-corruption office. ${ }^{48}$ The decision of the Court to classify the remedy provided for by Article 14.2 as an action for annulment relied on both a literal and a teleological reading of that provision. The Court indeed found objective similarities with Article 263 TFEU (length of the appeal period, nature of the pleas, identity of potential applicants). More fundamentally, the Court deemed this derogation from the general distribution of powers between national courts and EU courts justified in view of the 'particular institutional context in which the ESCB operates' ${ }^{49}$ The Court indeed considered that 'the ESCB represents a novel legal construct in EU law which brings together national institutions, namely the national central banks, and an EU institution, namely the ECB, and causes them to cooperate closely with each other, and within which a different structure and a less marked distinction between the EU legal order and national legal orders prevails'. ${ }^{\circ}$ Further building upon the hybrid status of the governors of national central banks under the $\mathrm{ESCB}^{51}$ and the centrality of the principle of independence in the ESCB's operations ${ }^{52}$, the Court thus found that only a proper action for annulment is capable of addressing the concerns which led to the creation

46 Case C-202/18 Ilmārs Rimšēvičs and European Central Bank v Republic of Latvia [2018] EU:C:2018:1030, Opinion of AG Kokott, paras 40, 36-68.

47 Rimšēvičs, paras 88-96.

48 Rimšēvičs, para. 97.

49 Rimšēvičs, para. 69.

50 Rimšēvičs, para. 69.

${ }^{51}$ Rimšēvičs, paras 70-71.

52 Rimšēvičs, paras 72-73. 
of that legal remedy [Article 14.2 of the ESCB Statute]' ${ }^{53}$ Rimšêvičs does constitute the first instance of an EU Court directly annulling an act of national law and extracting it from its domestic legal order. In that it goes beyond the principled separation of legal orders which thus far had governed the EU legal space, and beyond the general distribution of powers between EU and national courts flowing from it, it has been described as 'a revolution with the potential of changing EU law forever'. ${ }^{4}$ According to Bast, Rimšēvičs pushes the EU 'one step further along the federal path to fusing EU law and Member States law into one single legal order', as it highlights 'the common foundations and cooperative elements of the European constitutional order' ${ }^{55}$

Of course, one should be careful not to read too much into Rimšēvičs. As the Court itself puts it, ${ }^{6}$ the remedy at stake is very specific, and the issue it is designed to address (threats to the constitutional principle of central bank independence) is a very particular and grave one. More generally, the institutional framework it is part of, i.e. that of the ESCB, is characterized by the highest level of integration and centralization. It indeed relates to a policy field, monetary policy, which belongs fully and exclusively to the EU. If the ESCB is a multilevel administrative system, decision-making is as a matter of principle concentrated at the supranational level, the state level being solely relied upon for implementation purposes. Hazardous analogies derived from Rimšēvičs ought thus to be avoided. One can however not help drawing a parallel between the institutional context in which Rimšēvičs was decided and that of the SSM, on which this note focuses. ${ }^{57}$ It is our view that the SSM, just like the ESCB, can be characterized, to paraphrase the ECJ, as a 'novel legal construct' bringing together national institutions (the 19 internal supervisors of the participating countries) and an EU institution (the ECB), which requires them to cooperate closely according to a highly centralized, integrated and hierarchical template. Under this mechanism, national supervisory authorities also enjoy a hybrid status, not very dissimilar to that of national governors under the ESCB. Following a composite format directly inspired from that of the Governing Council of the ECB, the Supervisory Board, the main organ in charge of financial super-

53 Rimšēvičs, para. 74.

54 D. Sarmiento, 'Crossing the Baltic Rubicon' (Verfassungsblog, 4 March 2019) verfassungsblog.de/crossing-the-baltic-rubicon/ accessed 11 October 2019.

55 J. Bast, 'Autonomy in Decline? A Comment on Rimsevics and ECB v Latvia' (Verfassungsblog, 13 May 2019) verfassungsblog.de/autonomy-in-decline-a-commentary-on-rimsevics-and-ecb-vlatvia/ accessed 11 October 2019.

56 According to the Court, Article 14.2 of the Statute of the ESCB establishes a remedy which is 'very specific, as is apparent from the very small number of persons to whom it is available, the unique subject matter of the decisions against which it may be used and the exceptional circumstances in which it may be exercised' (Rimšēvičs, para. 71).

57 For a similar intuition, see R. Smits, 'ECJ annuls a national measure against an independent central banker’ (European Law Blog, 5 March 2019) europeanlawblog.eu/2019/03/o5/ecj-annulsa-national-measure-against-an-independent-central-banker/ accessed 11 October 2019 . 
vision within the ECB structure ${ }^{58}$ is composed of a Chair and a vice-Chair, four representatives of the ECB and one representative from each participating national supervisory authority. ${ }^{59}$ The independence of Board members is moreover guaranteed (Article 19). As a consequence, one may argue that the highly integrated nature of the SSM, and the composite nature of the administrative procedures that constitute it, contributes to blurring the dividing line between the EU legal order and national legal orders, just like under the ESCB. Berlusconi can certainly be read along these lines. But would the Court go as far as directly annulling preparatory acts adopted by national supervisors? This may seem farfetched, but Rimšēvičs, as a ruling which dramatically increases the interweaving of EU law and national law, ${ }^{60}$ would certainly constitute a useful precedent in that regard. ${ }^{61}$ Only time will tell if the Court stands ready to take such a leap.

\subsection{What the Berlusconi ruling left open. More preliminary questions waiting to happen?}

However clear and explicit the Court's pronouncements in Berlusconi may have been, the decision begs further questions, and raises new issues that future case law will have to address.

The first set of questions pertains to the concrete implementation of the extended type of (single) judicial review the Court established in Berlusconi. In its view, irregularities, either procedural or substantive, affecting the preparatory acts national supervisory bodies draw up under the SSM do automatically contaminate the ECB decisions freely following upon and endorsing these acts, in such a way that they are for the ECJ and not national courts to investigate, to establish and to sanction.

The question which arises is however which irregularities could be reviewed by the ECJ. The field of EU financial and banking law - whereby accordingly financial supervision is carried out under the SSM - is not fully preempted by EU law, which is on many counts complemented or further specified by national law. ${ }^{62}$ The body of prudential rules that is to be supervised under the SSM

$5^{8}$ It should however be noted that the Board does not adopt final decisions. Its draft supervisory decisions are indeed to be endorsed by the Governing Council following a non-objection procedure.

59 Article 26(1) of the SSM Regulation.

6o R. Smits, 'ECJ annuls a national measure against an independent central banker' (European Law Blog, 5 March 2019) europeanlawblog.eu/2019/03/05/ecj-annuls-a-national-measureagainst-an-independent-central-banker/ accessed 11 October 2019.

61 The main counter-argument lies in the fact that however ambiguous its formulation may be, Article 14.2 of the ESCB did provide a textual basis for the Court's ambitious move in Rimševičs. Such textual basis would however be clearly lacking in the case of the SSM.

62 One of the most remarkable features of the SSM is that the ECB itself, when carrying out its tasks as chief financial supervisor of the EU, is to directly apply all relevant national law provisions (Article 4(3) of the SSM Regulation). This unprecedented feature raises many issues, which are progressively being brought to the attention of the Court. In that regard, see L. 
framework is indeed partly contained in directly applicable EU law (regulations), ${ }^{6}$ but also consists of directives which are to be further transposed in national legislation. ${ }^{64}$ Moreover, EU instruments in the field also grants Member States dozens of options, which they are to exercise through national instruments. ${ }^{65}$ Finally, general administrative procedural requirements, such as the right to be heard, the duty to give reasons, or the principle of legitimate expectations, continue to apply if and to the extent that these are foreseen by general domestic administrative law. The ensuing question is therefore whether only irregularities under EU law or also potentially irregularities under national law fall within the jurisdiction of the ECJ as a consequence of the Berlusconi ruling. The ruling in the Berlusconi case does not directly answer this question.

A useful starting point can be found in Advocate General Mischo's Opinion in Association Greenpeace France. ${ }^{66}$ In his view, it was 'impossible to see how the Community Court, which has sole jurisdiction to declare a Community act invalid, could form an opinion as to the existence of an irregularity with respect to national law'. Indeed, as also argued by Brito Bastos, one of the conditions for the court to accept the "derivative illegality" of EU decisions based on unlawful national preparatory decisions is that only illegalities under EU law are to be reviewed by the Court. As he observes:

'[T] he purpose of this condition is twofold. First, to ensure that the assessment of the legality of final EU measures is based exclusively on rules of EU law, as the principle of the autonomy of the EU legal order dictates. Second, the condition responds to the need to preserve the limits of the jurisdiction of EU courts, which are only competent to interpret and apply EU law. ${ }^{67}$

However, the consequence of this limitation is clearly that irregularities under national law, which nevertheless remains applicable, will not be subject to control by any judicial forum. This constitutes a clear vulnus to the rule of

Boucon and D. Jaros (n31) 155-187. See also, for an overview of the relevant case law, M. Prek and S. Lefèvre (n3o) 104-105.

63 The main instrument in this category is the Capital Requirements Regulation. See Regulation $575 / 2013$ of the European Parliament and of the Council of 26 June 2013 on prudential requirements for credit institutions and investment firms and amending Regulation 648/2012 [2013] OJ L176/1.

64 The most prominent example is the Capital Requirements Directive IV (CRD IV). See Directive $2013 / 36 / E U$ of the European Parliament and of the Council of 26 June 2013 on access to the activity of credit institutions and the prudential supervision of credit institutions and investment firms, amending Directive 2002/87/EC and repealing Directives 2006/48/EC and 2006/49/EC [2013] OJ L176/338.

65 In this regard, see European Banking Authority, 'Overview of options and discretions set out in Directive 2013/36/EU and Regulation (EU) No. 575/2013’ eba.europa.eu/supervisory-convergence/supervisory-disclosure/options-and-national-discretions accessed 26 June 2019.

66 Case C-6/99 Association Greenpeace France and Others $v$ Ministère de l'Agriculture et de la Pêche and Others [1999] EU:C:1999:587, Opinion of AG Mischo, para. 98.

67 F. Brito Bastos (n1) 126. 
law. The opposite solution, the ECJ ruling on national supervisors' abidance with pure national law elements, also raises many questions. One may doubt the court's ability to do so, in view of the insufficient knowledge it may have of the relevant national legal system, and the applicable regulatory framework. Moreover, it is unclear how far the Court could go in terms of fact-finding, and how its concrete assessment of the national phase of the procedure is to be carried out. ${ }^{68}$ Even more importantly, law is often to be interpreted, and one may wonder to what extent the ECJ would be bound by the interpretations favored by national courts. ${ }^{69}$ As a matter of principle, the Court tends to follow the interpretation of national courts, without second-guessing them or questioning their legitimacy. ${ }^{70}$ However, what happens if such interpretation is not available, or remains unclear? Would the Court be able to freely interpret national law?

Finally, and perhaps most importantly, the structure of the EU legal system, and the autonomy of both the EU and the national legal orders, would advise against this kind of initiative, which may harm the uniformity of national law. Unfortunately, the Treaties do not foresee any mechanism through which the Court might request the opinion of national courts as to matters of interpretation of national law (a 'reverse' preliminary ruling procedure). The question of whether the Court of Justice would review national preparatory measures also against national law remains therefore unanswered.

Moving now to the procedural consequences of the Court's review of national preparatory measures, the question arises as to the 'procedural fate' of such measures. Does Berlusconi imply, at least tacitly, that the Court is entitled to annul erga omnes the preparatory acts irregularly adopted by national supervisors under the SSM? While the abovementioned Rimšêvičs ruling might - at least indirectly - indicate that this may be a possible reading, the Court in Berlusconi seems to be - at least explicitly - excluding that possibility. Its indication that single judicial review by EU courts can only be envisaged 'once the decision of the EU institution bringing the administrative procedure to an end has been

68 This point is noted specifically by Demkova who argues, in light of established case law, that the 'interpretation of facts arising under national law rests solely with the national courts'. She however considers that it ought to be possible for EU courts to undertake a full review of all relevant facts on the basis of the EU principle of duty of care. S. Demková, 'The Grand Chamber's Take on Composite Procedures under the Single Supervisory Mechanism: Comments on Judgment of 27 June 2018, C-219/17 Silvio Berlusconi v Finanziaria d'investimento Fininvest SpA (Fininvest) v Banca d'Italia and others, EU:C:2018:502' (2019) 12 REALaw 209.

69 This issue, particularly pregnant in the case of the SSM, is not unique to prudential supervision. On this issue in general, see M. Prek and S. Lefèvre, "The EU Courts as "national courts" - National law in the EU judicial process' (2017) 54 CMLR 369.

70 See K. Lenaerts, I. Maselis and K. Gutman, EU Procedural Law (OUP 2015) 233-234 and case law herein cited. 
adopted ${ }^{171}$ suggests that the actual 'object' of judicial review is only this final EU act, which will be the only measure subject to annulment. What concretely is the 'destiny' of the contaminating national preparatory measure (annulment erga omnes, disapplication inter partes, or something else) remains unclear. However, it could be argued that in any case, on the basis of the principle of loyal cooperation, national authorities would have the duty to ensure that an invalid national preparatory measure is no longer applied and - if needed - to adopt a new, valid, measure.

Finally, one may wonder to what extent the Court's findings in Berlusconi, and the centralized model of judicial review it consecrates, could be replicated in other settings. ${ }^{72}$ Let us first turn to other procedures carried out under the SSM framework. It is very clear that Berlusconi, concerning a procedure granting authorizations for acquisitions of qualifying holdings in credit institutions (Article 4(1)(c) of the SSM Regulation), could be applied in the context of the other two so-called 'common procedures', namely the granting and the withdrawal of authorizations to operate as a credit institution (Article 4(1)(a) of the SSM Regulation). By extension, Berlusconi's ratio decidendi could also be applied to all other SSM procedures meeting the criteria identified in Berlusconi, i.e. procedures involving NCAs at a preparatory stage (and responsible for a first assessment and the preparation of draft decisions) and culminating with a final, discretionary decision of the ECB. ${ }^{73}$ One may also ask about the relevance of Berlusconi for other policy fields, and other complex administrative settings. It is foreseeable that the Berlusconi ruling might also find application with respect to other composite procedures, where the decision-making process culminates at the EU level and is based on a series of non-binding national preparatory steps, such as customs ${ }^{74}$ or funds. ${ }^{75}$

What however remains still unclear is the applicability of either the Borelli or the Berlusconi rulings, first of all, to composite procedures having more than one step, such as the marketing authorization of GMOs and, second of all,

Berlusconi, para. 49. See also Case 6o/81 IBM Corporation v Commission [1981] EU:C:1981:264, paras 10-11.

72 It should be noted that in the recent Iccrea ruling, the Court has confirmed the applicability of its finding in Berlusconi in the neighbouring context of the composite procedures of the Single Resolution Mechanism. See Case C-414/18, Iccrea Banca, ECLI:EU:C:2019:1036

73 Think for instance of the situation where the $\mathrm{ECB}$, in the framework of direct prudential supervision, relies on the assistance of NCAs (Article 6(3) of the SSM Regulation), for example by instructing NCAs to make use of some of their powers (Article 22 of the SSM Framework Regulation), and subsequently adopts a supervisory decision the content of which is the direct product of such use.

74 E.g. in the case of France-aviation, a provision concerning the repayment of import duties was at stake. Case T-346/94 France-aviation v Commission [1995] EU:T:1995:187.

75 E.g. in the case of Branco, the procedure concerned the repayment of expenditures made at the national level on the basis of an EU programme on vocational training: Case T-85/94 Branco [1995] EU:T:1995:4. 
where the national contribution might not entail a formal 'opinion' or 'draft measure', but something much more 'intangible' and 'diluted', such as the stating of objections or the provision of information. ${ }^{76}$ Furthermore, what these cases leave open is the treatment of national preparatory measures taken in the context of horizontal composite procedures for the implementation of EU law, where there is no involvement of the EU authorities, but only various forms of cooperation between national authorities. To what extent can any of the case law on composite procedure be applied in a situation where two national authorities, for example, cooperate for the purposes of deciding on a marketing authorization for a pharmaceutical product? As AG Bobek put in a recent opinion, 'the territorial nature of each of the marketing authorisations and the necessary correlating territorial nature of judicial review' will create obstacles to the control of acts or actions originating in another jurisdiction..$^{77}$ It is therefore not unlikely that it will not take long until the topic of composite procedures, in its many facets, will soon again come to the attention of the Court.

\section{Conclusions}

The Berlusconi ruling contributes to the growing body of case law on the legal nature of the SSM and to that concerning the division of jurisdiction between national and European courts in the context of composite procedures. It clarifies that, whenever a multi-level decision-making process starts at the national level and culminates with a decision made by the EU authorities, the determining factor for assigning jurisdiction to the national or the European level is the question of whether the unlawful national preparatory measure was binding upon (and is thus de facto not imputable to) the EU authorities. If so, the jurisdiction to control the national preparatory measure belongs to the national judiciary. In the opposite case, when the unlawfulness of the national preparatory measure was endorsed, through the exercise of discretionary powers, by the EU authorities, jurisdiction for the entirely of the process belongs to the European courts. This solution seems to be in line with the earlier case law of the Court of Justice and fully preserves the autonomy of the EU legal order. However, it also creates the risks of gaps of judicial control if the European courts' control is limited to possible illegalities under EU law. This, together with the questions regarding what division of labour ought to apply in more 'diluted' or fully 'horizontal' cases of composite procedures, remains unanswered.

\footnotetext{
${ }^{6}$ For a discussion on this point, with focus on banking supervision see A. Türk and N. Xanthoulis, 'Legal accountability of European Central Bank in bank supervision: A case study in conceptualizing the legal effects of Union acts' (2019) 26 MJECL 151.

77 Case C-557/16 Astellas Pharma GmbH [2017] EU:C:2017:957, Opinion of AG Bobek, para. 92.
} 